\title{
Detection of Snow Mold Fungi in Wheat Plants by Means of Polyacrylamide Gel Electrophoresis of Ribosomal Proteins
}

\author{
Shigehito Takenaka* and Reiichi Yoshino**
}

\begin{abstract}
Ribosomes were isolated from four snow mold fungi (Pythium paddicum, P. iwayamai, Typhula incarnata and Fusarium nivale) and wheat seedlings, and their proteins were analyzed by SDS-polyacrylamide gel electrophoresis (SDS-PAGE). No difference was found in electrophoretic patterns between $P$. paddicum and $P$. iwayamai. However, there were several differences among two Pythium species, T. incarnata, F. nivale and wheat. The ribosomes were isolated also from wheat seedlings infected with $P$. paddicum, $T$. incarnata and $F$. nivale individually, and their proteins were analyzed by SDS-PAGE. The distinctive fungal ribosomal protein bands were detected in all patterns obtained from the infected wheat plants. The possibility of the ribosomal protein-based assay to detect snow mold fungi in wheat plants is suggested.
\end{abstract}

(Received April 27, 1987)

Key words : snow mold fungi, electrophoresis, fungal ribosomal proteins, diagnosis.

\section{Introduction}

In Hokuriku area in Japan, three snow mold diseases have occurred on winter wheat plants (Triticum aestivum L.). The first is Pythium snow rot caused by $P$. paddicum, P. iwayamai and other Pythium spp. ${ }^{2}$, the second is gray snow mold caused by Typhula incarnata, and the third is pink snow mold caused by Fusarium nivale. These diseases have occurred coexistently rather than singly in the fields. At present, diseased plants are diagnosed by observation of symptoms or by isolation and identification of the pathogen. However, the symptoms of these diseases are often similar and the culture method can be unreliable because a fast growing fungus may overgrow other fungi within a few days. Therefore, a new method has been required for the detection of the causual fungi in infected plants.

Marshall and Partridge ${ }^{6,7)}$ utilized ribosomal protein differences between a parasite and a host plant to detect $F$. moniliforme in stalk rotted corn. Eukaryotic ribosomes contain $70-80$ different proteins ${ }^{12}$, and in general there is no qualitative difference in ribosomal proteins from diverse tissues or organs and from various stages of develop-

* Hokuriku National Agricultural Experiment Station, Joetsu, Niigata 943-01, Japan 農林水産省 北陸農業試験場

** Present address : National Agriculture Research Center, Yatabemachi, Ibaraki 305, Japan 現 在：農林水産省農業研究センター 
ment of the same species ${ }^{13)}$. Furthermore, previous studies ${ }^{1,10,12,13)}$ have shown that there were electrophoretic and serological differences among the ribosomal proteins of different organisms. These studies suggest that the ribosomal protein-based assay has the potential to detect the snow mold fungi in host plants.

In this paper, we describe the comparison of ribosomal proteins of four snow mold fungi and a wheat plant, and the detection of fungal ribosomal proteins in infected plants by SDS-polyacrylamide gel electrophoresis (SDS-PAGE).

\section{Materials and Methods}

Materials. Ten isolates of snow mold fungi shown in Table 1 were used for ribosome extraction. Isolates of $P$. paddicum, $P$. iwayamai and $F$. nivale were grown in potato sucrose broth at $15 \mathrm{C}$ for $1-3$ weeks, and $T$. incarnata isolates were grown at $10 \mathrm{C}$ for 4-8 weeks. The mycelial mats were harvested by centrifugation or filtration, washed repeatedly with distilled water and stored at $-80 \mathrm{C}$. Two cultivars (Nōrin No. 61, Yukichabo) and one line (Tōsan No. 16) of wheat plants were grown in a glasshouse until 1-1.5 leaf stage and leaves were harvested for ribosome extraction. To obtain infected plants, wheat seedlings at 3-3.5 leaf stage were inoculated with P. paddicum, $T$. incarnata and $F$. nivale individually by artificial inoculation method ${ }^{11)}$.

Ribosome extraction. The frozen materials of fungal and plant tissues were ground and homogenized with a mortar and pestle in two volumes of buffer $\mathrm{A}^{6)}(50 \mathrm{mM}$ Tris- $\mathrm{HCl}, \mathrm{pH} 8.5,60 \mathrm{mM} \mathrm{KCl}, 30 \mathrm{mM} \mathrm{MgCl}_{2}, 0.2 \mathrm{M}$ sucrose) containing $5 \mathrm{mM} 2$-mercaptoethanol. The homogenate was filtered through a double-layer of cheesecloth (the filtration was omitted for fungal homogenate) and centrifuged at $21,500 \times \mathrm{g}$ for $30 \mathrm{~min}$ at $4 \mathrm{C}$. The supernatant, ca. $8 \mathrm{ml}$ per tube, was layered on a $1.5 \mathrm{ml}$ pad of $1.5 \mathrm{M}$ sucrose in buffer A containing $5 \mathrm{mM} \mathrm{2-mercaptoethanol,} \mathrm{and} \mathrm{centrifuged} \mathrm{at} 189,400 \times g$ for $4 \mathrm{hr}$ at $4 \mathrm{C}$. The resulting ribosomal pellet was resuspended in buffer $\mathrm{B}^{6}$ ) $(20 \mathrm{mM}$ Tris- $\mathrm{HCl}$, $\mathrm{pH} 7.5,20 \mathrm{mM} \mathrm{KCl}, 10 \mathrm{mM} \mathrm{MgCl}_{2}$ ) and the suspension was centrifuged at 23,000 $\mathrm{g}$ for $5 \mathrm{~min}$ at $4 \mathrm{C}$. For further purification, the crude ribosomal suspension, less than

Table 1. Fungal isolates used

\begin{tabular}{l|l|l}
\hline \hline Isolate & \multicolumn{1}{|c|}{ Species } & Geographic origin \\
\hline $\mathrm{H}-82^{-73^{\mathrm{a}}}$ & Pythium paddicum & Imajō-Chō, Fukui \\
$\mathrm{P}-7^{\mathrm{a})}$ & P. paddicum & Sabae-Shi, Fukui \\
$\mathrm{W}-82-15^{\mathrm{a})}$ & P. paddicum & Asahi-Chō, Fukui \\
$\mathrm{W}-82-50^{\mathrm{a})}$ & P. iwayamai & Takefu-Shi, Fukui \\
$\mathrm{HT} 8301$ & Typhula incarnata & Jōetsu-Shi, Niigata \\
$\mathrm{HT} 8302$ & T. incarnata & Ishikawa \\
Wh63D & T. incarnata & Kuroisi-Shi, Aomori \\
$\mathrm{HS}-50^{\text {a) }}$ & Fusarium nivale & Ōno-Shi, Fukui \\
$\mathrm{HF} 8001$ & F. nivale & \\
$\mathrm{HF} 8301$ & F. nivale & Jōetsu-Shi, Niigata \\
\hline
\end{tabular}

a) Supplied by Mr. S. Takamatsu, Fukui Agricultural Experiment Station.

b) Supplied by Mr. N. Matsumoto, Hokkaido National Agricultural Experiment Station. 
$72 \mathrm{~A}_{260}$ units per tube, was layered onto $10-35 \%(\mathrm{w} / \mathrm{v})$ linear sucrose density gradient in buffer B, centrifuged in a Hitachi RPS 25 rotor at $52,000 \times g$ for $5 \mathrm{hr}$ at $4 \mathrm{C}$, and fractionated into 30 fractions. Two $\mathrm{ml}$ of buffer $\mathrm{B}$ was added to each fraction and absorbance at $260 \mathrm{~nm}$ was measured with a Shimazu UV-240 spectrophotometer. The monosome and polysome regions of these fractions were collected, and centrifuged at $189,400 \times \mathrm{g}$ for $2 \mathrm{hr}$ at $4 \mathrm{C}$ after adding $5 \mathrm{mM} 2$-mercaptoethanol. The resulting pellets were suspended in a small volume of $50 \mathrm{mM}$ Tris- $\mathrm{HCl}, \mathrm{pH} 8.8$, and the suspension was centrifuged at $10,000 \mathrm{rpm}$ for $2 \mathrm{~min}$ in a Hitachi RPR 18-3 rotor. The resulting supernatant was stored at $-80 \mathrm{C}$ for use as the purified ribosomal suspension.

SDS-PAGE. After adding equal volumes of dissociation buffer (50 mM Tris-HCl, $\mathrm{pH}$ 8.8, 4\% SDS, 2\% 2-mercaptoethanol), the purified ribosomal suspension was heated at $100 \mathrm{C}$ for $5 \mathrm{~min}$. The dissociated samples ( $1.0 \mathrm{~A}_{260}$ unit per well) were electrophoresed in a $10 \%$ polyacrylamide vertical slab gel, $14 \times 10 \times 0.2 \mathrm{~cm}$, by using the discontinuous buffer system described by Laemmli5). For the molecular weight (mol. wt.) determinations, phosphorylase $a$ (mol. wt. $92.5 \times 10^{3}$ daltons), bovine serum albumin (66 $\left.\times 10^{3}\right)$, aldolase $\left(39 \times 10^{3}\right)$, carbonic anhydrase $\left(28.8 \times 10^{3}\right)$, tobacco mosaic virus coat protein $\left(17.5 \times 10^{3}\right)$ and cytochrome $c\left(12.3 \times 10^{3}\right)$ were used as marker proteins.

\section{Results}

\section{Yield and quality of extracted ribosomes}

The extraction procedure yielded an average of $14.6 \mathrm{~A}_{260}$ units/g of crude ribosomal suspensions from $P$. paddicum and $P$. iwayamai, $11.0 \mathrm{~A}_{260}$ units $/ \mathrm{g}$ from $T$. incarnata, 8.0 $\mathrm{A}_{260}$ units/g from $F$. nivale and $7.7 \mathrm{~A}_{260}$ units/g from wheat in fresh weight. When these crude ribosomal suspensions were centrifuged through a sucrose density gradient, monosome and smaller polysome peaks were detected. In particular, the monosome was predominant in $P$. paddicum and $P$. iwayamai preparations, which was probably due to polysome degradation by RNase or divalent cations in tissue ${ }^{3)}$. The average $A_{260} / A_{235}$ and $A_{260} / A_{280}$ ratios of ribosomes taken after the sucrose density gradient centrifugation were $1.84,2.04$ for two Pythium species ribosomes, $1.79,2.00$ for T. incarnata, 1.67, 2.00 for $F$. nivale and $1.73,1.99$ for wheat. The less the extraneous proteins are present in a ribosomal preparation, the higher the $A_{260} / A_{235}$ ratio is obtained ${ }^{8)}$. Petermann and Pavlovec ${ }^{9)}$ reported that the $A_{260} / A_{235}$ ratio of the ribosomal fraction was 1.67 , which showed no extraneous proteins on electrophoretic analysis. This suggests that our ribosomal preparations were relatively free of extraneous proteins.

\section{SDS-PAGE patterns of ribosomal proteins of snow mold fungi and wheat}

Ribosomal preparations from snow mold fungal isolates and wheat plants were examined (Fig. 1). Within each species, there was no obvious difference in the electrophoretic patterns. To compare the ribosomal proteins of four different snow mold fungi and wheat, each preparation was run on the same gel (Fig. 2). No difference was found in the electrophoretic patterns between $P$. paddicum and $P$. iwayamai. However, there were several differences among two Pythium species, $T$. incarnata, F. nivale and wheat. Qualitative differences were recongnized below mol. wt. of $33 \times 10^{3}$ daltons (33K) among 


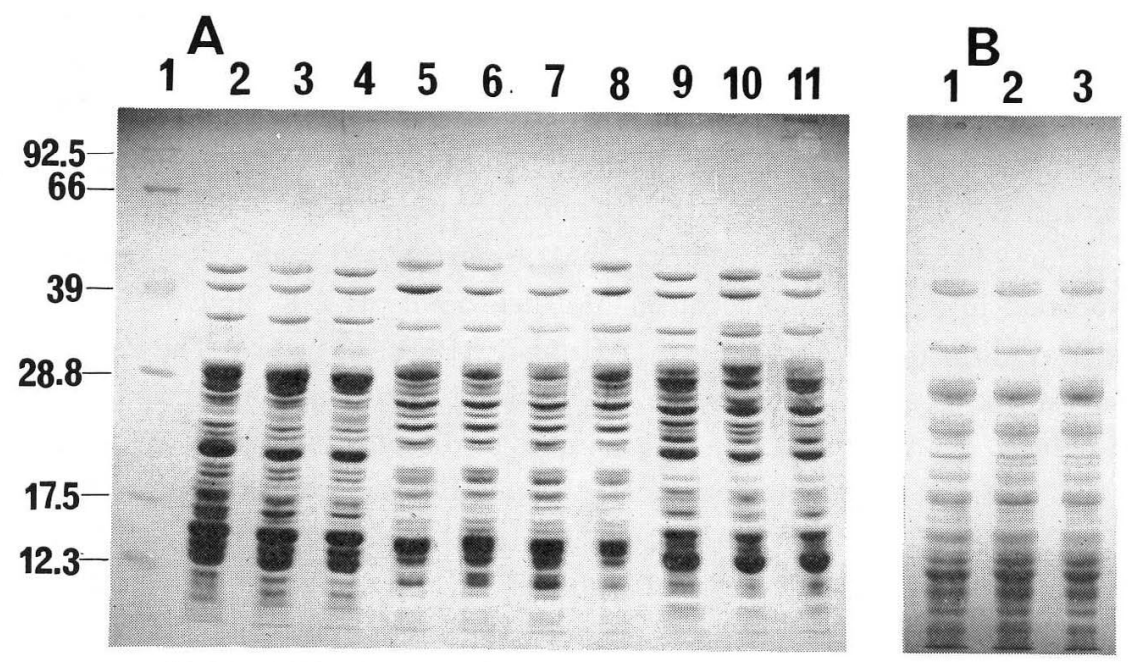

Fig. 1. SDS-PAGE patterns of ribosomal proteins of snow mold fungal isolates (A) and wheat plants (B). A: (lane 1) marker proteins ( $\times 10^{3}$ daltons, see Materials and Methods). (lane 2) HS-50. (lane 3) HF8001. (lane 4) HF8301. (lane 5) W-82-50. (lane 6) H-82-73. (lane 7) P-7. (lane 8) W-82-15. (lane 9) HT8302. (lane 10) Wh63D. (lane 11) HT8301. B: (lane 1) Nörin No. 61. (lane 2) Yukichabo. (lane 3) Tōsan No. 16.

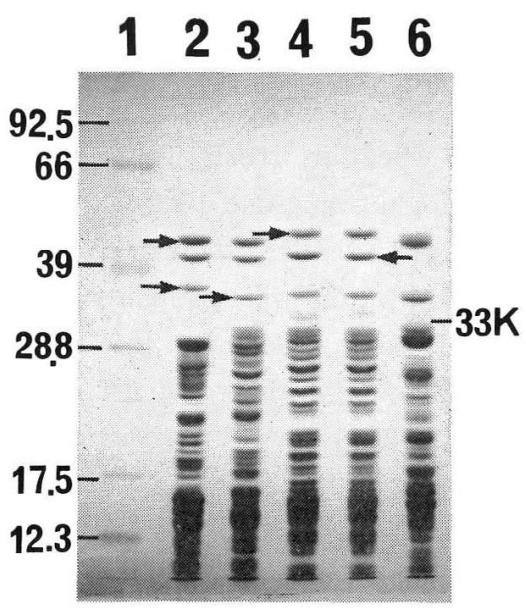

Fig. 2. SDS-PAGE patterns of ribosomal proteins of four snow mold fungi and wheat. (lane 1) marker proteins ( $\times 10^{3}$ daltons, see Materials and Methods). (lane 2) Fusarium nivale. (lane 3) Typhula incarnata. (lane 4) Pythium iwayamai. (lane 5) P. paddicum. (lane 6) wheat. The arrows indicate the distinctive bands above mol. wt. of $33 \times 10^{3}$ daltons (33K).

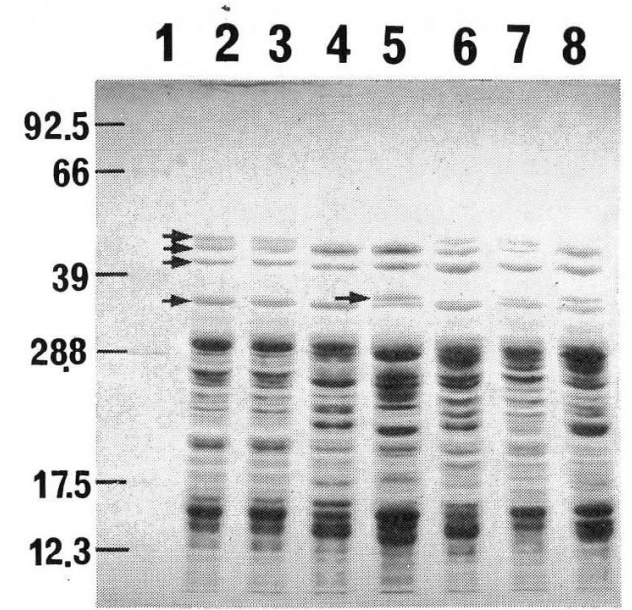

Fig. 3. SDS-PAGE patterns of ribosomal protein mixtures. Two ribosomal preparations wcre mixed $(1: 1)$ and co-electrophoresed. (lane 1) marker proteins ( $x$ $10^{3}$ daltons, see Materials and Methods). (lane 2) wheat + Pythium paddicum. (lane 3) wheat $+P$. iwayamai. (lane 4) wheat + Typhula incarnata. (lane 5) wheat + Fusarium nivale. (lane 6) $P$. paddicum $+T$. incarnata. (lane 7) $P$. paddicum $+F$. nivale. (lane 8) $T$. incarnata $+F$. nivale. The arrows indicate the distinctive bands of fungal and. wheat ribosomes. 


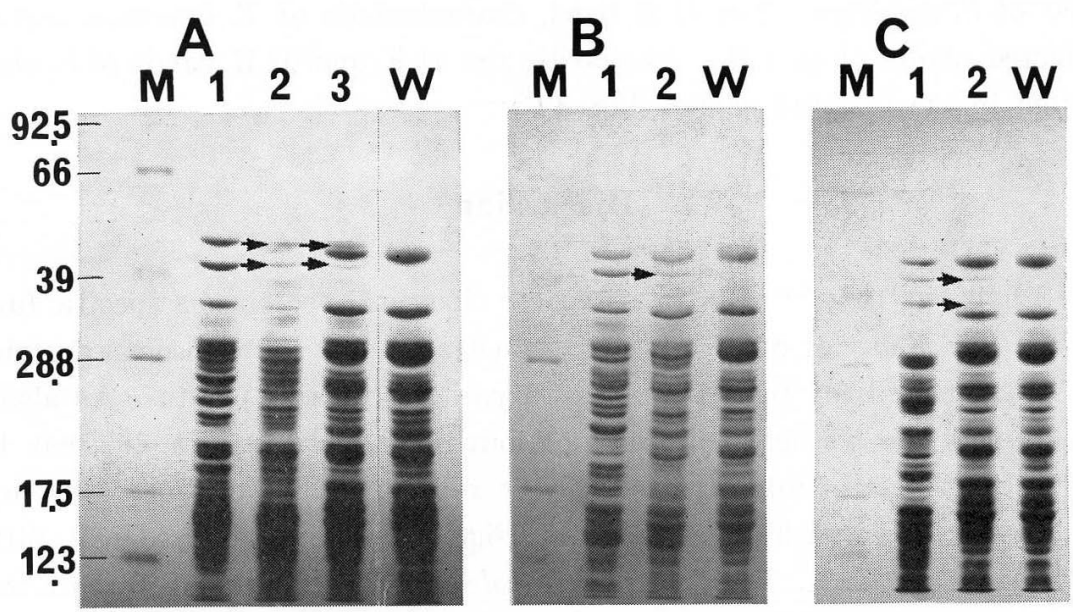

Fig. 4. Detection of fungal ribosomal proteins in the electrophoretic patterns obtained from wheat seedlings inoculated with Pythium paddicum (A), Typhula incarnata (B) and Fusarium nivale (C). $\mathrm{M}$ and $\mathrm{W}$ represent marker proteins ( $\times 10^{3}$ daltons, see Materials and Methods) and the healthy wheat ribosomal pattern, respectively. A : (lane 1) P. paddicum. (lane 2) wheat seedlings 14 days after inoculation. (lane 3) wheat seedlings 11 days after inoculation. B: (lane 1) T. incarnata. (lane 2) wheat seedlings 14 days after inoculation. C: (lane 1) F. nivale. (lane 2) wheat seedlings 14 days after inoculation. The arrows indicate the distinctive fungal bands.

these ribosomal proteins. Qualitative differences were also found in ribosomal proteins above $33 \mathrm{~K}$. From $P$. paddicum and $P$. iwayamai ribosomes, three kinds of polypeptides with $47 \mathrm{~K}, 41 \mathrm{~K}$ and $35 \mathrm{~K}$ were detected. T. incarnata ribosome contained three kinds of polypeptides with $45 \mathrm{~K}, 41 \mathrm{~K}$ and $35 \mathrm{~K}$. F. nivale ribosome revealed three kinds of polypeptides with $45 \mathrm{~K}, 41 \mathrm{~K}$ and $37 \mathrm{~K}$. From wheat ribosome, only two kinds of polypeptides with $45 \mathrm{~K}$ and $35 \mathrm{~K}$ were detected. These findings indicate that the $41 \mathrm{~K}$ band is characteristic of fungal ribosomes. When two ribosomal preparations were mixed in equal quantities and co-electrophoresed, the distinctive bands of respective fungal ribosomes could be detected in the composite pattern (Fig. 3). For example, the $47 \mathrm{~K}$ and $35 \mathrm{~K}$ bands, characteristic of P. paddicum, and the $45 \mathrm{~K}$ and $37 \mathrm{~K}$ bands, characteristic of F. nivale, were found in the composite pattern of these fungi (Fig. 3, lane 7).

\section{Detection of fungal ribosomal proteins in infected plants}

The ribosomes were extracted from wheat seedlings infected with $P$. paddicum, $T$. incarnata and F. nivale individually, and were electrophoresed along with those of each pathogen and wheat (Fig. 4). The distinctive fungal bands were detected in all preparations of the infected wheat plants. The $47 \mathrm{~K}$ and $41 \mathrm{~K}$ bands, which were characteristic of $P$. paddicum ribosome, were detected in two electrophoretic patterns of the plants infected with this pathogen (Fig. $4 \mathrm{~A}$, lane 2 and 3). The electrophoretic pattern obtained from the plants 11 days after inoculation was similar to that of the healthy plants, whereas the pattern obtained from the plants 14 days after inoculation was sim- 
ilar to that of $P$. paddicum. The $41 \mathrm{~K}$ band, characteristic of $T$. incarnata, was detected in the infected plants (Fig. $4 \mathrm{~B}$ ). Similarily, the $41 \mathrm{~K}$ and $37 \mathrm{~K}$ bands of $F$. nivale were also detected in the infected plants (Fig. $4 \mathrm{C}$ ).

\section{Discussion}

Marshall and Partridge ${ }^{67}$ characterized the ribosomal proteins as specific fungal proteins in Fusarium stalk rot of corn, and demonstrated that the ribosomal protein differences could be utilized for the detection of a parasite in host plants. We also studied the comparison of the ribosomal proteins of four snow mold fungi and wheat by SDSPAGE. These ribosomal protein patterns were reproducible in different electrophoretic runs, and were uniform within each species (Fig. 1). There were several differences among two Pythium species, T. incarnata, F. nivale and wheat, but no difference was found between the two Pythium species (Fig. 2). This suggests that at least the analysis of ribosomal proteins by SDS-PAGE can find the differences among these organisms belonging to different genera.

The distinctive fungal bands could be detected in wheat plants infected with P. paddicum, T. incarnata and F. nivale individually (Fig. 4). The electrophoretic pattern of ribosomal preparation from wheat seedlings 11 days after inoculation with $P$. paddicum was similar to that of healthy plants, while the pattern of wheat seedings 14 days after inoculation was similar to that of $P$. paddicum (Fig. 4 A, lane 2 and 3), indicating that the detection ratio of fungal ribosomes to wheat ones increased with progress of the infection. These findings suggest that the ribosomal protein-based assay can at least distinguish among two Pythium species, T. incarnata and F. nivale, in infected wheat tissues. On the basis of these results, we are attempting to develop the ribosomal protein-based assay by employing serological techniques for the diagnosis of snow mold diseases.

We are very grateful to Dr. Y. Shirako, Faculty of Agriculture, Tohoku University for his valuable suggestions on this work and reviewing this manuscript. We also thank to Mr. S. Takamatsu, Fukui Agricultural Experiment Station and Mr. N. Matsumoto, Hokkaido National Agricultural Experiment Station for supplying fungal isolates.

\section{Literature cited}

1. Gualerzi, C., Janda, H. G., Passow, H. and Stöffler, G. (1974). J. Biol. Chem. $249:$ 3347-3355.

2. Ichitani, T., Takamatsu, S. and Stamps, D. J. (1986). Ann. Phytopath. Soc. Japan 52:209-216.

3. Jackson, A. O. and Larkins, B. A. (1976). Plant Physiol. 57 : 5-10.

4. Kado, C. I., Schaad, N. W. and Heskett, M. G. (1972). Phytopathology 62 : 1077-1082.

5. Laemmli, U. K. (1970). Nature $227: 680-685$.

6. Marshall, M. R. and Partridge, J. E. (1981). Physiol. Plant Pathol. 18 : 133-141.

7. Marshall, M. R. and Partridge, J. E. (1981). Ibid. 19:277-288.

8. Petermann, M. L. (1964). The Physical and Chemical Properties of Ribosomes. Elsevier, Amsterdam. pp. 63-64.

9. Petermann, M. L. and Pavlovec, A. (1963). J. Biol. Chem. $238:$ 318-323.

10. Stöffler, G. (1974). In Ribosomes (Nomura, M. et al. eds.). Cold Spring Harbour Laboratory. pp. $615-667$.

11. Takenaka, S. and Yoshino, R. (1987). Ann. Phythopath. Soc. Japan $53: 566-569$. 
12. Wool, I. G. (1979). Ann. Rev. Biochem. $48: 719-754$.

13. Wool, I. G. and Stöffler, G. (1974). In Ribosomes (Nomura, M. et al. eds.). Cold Spring Harbour Laboratory. pp. 417-460.

\section{和 文 摘 要}

竹中重仁・吉野嶺一：リボソームタンパク質のポリアクリルアミドゲル電気泳動法によるコムギからの各種 雪鹰病菌の検出

4 種の雪閝病菌 (Pythium paddicum, P. iwayamai, Typhula incarnata および Fusarium nivale) とコムギ からリボソームを抽出し, SDS-ポリアクリルアミドゲル電気泳動法によって, それらのリボソームタンパク 質の泳動パターンを比較した。その結果, P. paddicum と P. iwayamai との間では泳動パターンに差異が認 められなかったが, 2 種の Pythium 菌, T. incarnata, F. nivale およびコムギの間では明らかな差異が認めら れた。また, P. paddicum, T. incarnata および F. nivale を各々接種したコムギからリボソームを抽出し， それらの泳動パターンを比較した結果，各種罹病コムギから病原菌のリボソームタンパク質のバンドが検出さ れた。これらの結果から, 各菌のリボソームタンパク質による本病の診断の可能性が示唆された。 